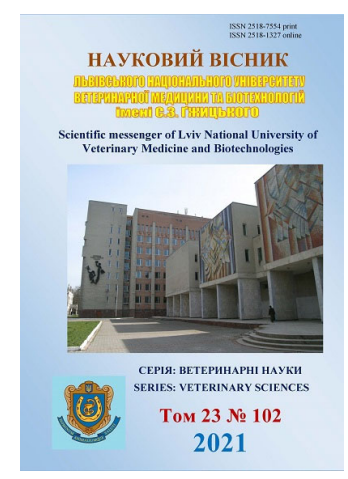

\section{Науковий вісник Дьвівського національного університету ветеринарної медицини та біотехнодогій імені С.3. Гжицыкого. Серія: Ветеринарні науки}

\author{
Scientific Messenger of Lviv National University \\ of Veterinary Medicine and Biotechnologies. \\ Series: Veterinary sciences
}

UDC 616.995.132:636.598:612.1

\title{
Morphological parameters of geese blood in amidostomy invasion
}

\author{
S. Mykhailiutenko ${ }^{1}, \mathrm{O}_{\text {. Zhulinska }}^{2}$
}

${ }^{1}$ Poltava State Agrarian Academy, Poltava, Ukraine

2 "Ascania-Nova" Institute of Animal Breeding in the Steppe Regions named after M. F. Ivanov - National Scientific Selection-Genetics Center for Sheep Breeding, Ascania-Nova, Ukraine

\section{Article info}

Received 19.04.2021

Received in revised form 24.05 .2021

Accepted 25.05.2021

Poltava State Agrarian Academy Skovorody Str., 1/3, Poltava 36003, Ukraine. Tel.: +38-066-630-54-44 E-mail:sv81@ukr.net

"Ascania-Nova" Institute of Animal Breeding in the Steppe Regions named after M. F. Ivanov - National Scientific Selection-Genetics Center for Sheep Breeding, Soborna Str., 1 Ascania-Nova, Chaplinka district, Kherson region, 75230 , Ukraine
Mykhailiutenko, S., \& Zhulinska, O. (2021). Morphological parameters of geese blood in amidostomy invasion. Scientific Messenger of Lviv National University of Veterinary Medicine and Biotechnologies. Series: Veterinary sciences, 23(102), 105-109. doi: 10.32718/nvlvet10216

The vital activity of the body of waterfowl depends on many factors, but primarily on the state of the erythrocytopoiesis system. This is a unique mechanism that occupies a dominant position in ensuring tissue respiration and stability of metabolic processes in the body. Based on research and analysis of publications, it can be argued that changes in erythrocytopoiesis indicate a pathological condition, which in the early stages of helminthiasis occurs without pronounced clinical signs. It is known that the nematode Amidostomum anseris - hematophagous. The condition of erythrocytopoiesis is most studied in cattle and carnivores. In Ukraine, not enough attention is paid to the study of morphological parameters in geese. Therefore, in order to determine the effect of amidost on the morphological parameters of sick goslings, an experimental group of birds aged 1.5 months, as well as a control group (eight heads in each) was formed. The work was performed in the conditions of individual peasant farms in the village of Decembrists of Myrhorod district of the Poltava region. Morphological parameters were studied according to generally accepted methods. The article summarizes the results of the experiment on the effect of amidostom on the performance of infested goslings of the large gray breed. It was found that parasitism in waterfowl species A. anseris led to changes in the overall analysis of the blood of geese: a decrease in hemoglobin by 8.39, the number of erythrocytes - $13.46 \%$, a significant increase in the number of leukocytes to 24.44 G/l. At the same time, a morphological study of the shaped elements of the bird's blood with a differential calculation of the leukocyte formula was performed. There was a decrease in the number of segmental neutrophils $(22.0 \pm 0.57)$ compared with the control group $(26.5 \pm 1.45)$ due to lymphocytes and monocytes, which, in our opinion, is associated with the adaptation of the organism to parasitism of nematodes. The results of morphological studies of the blood of infested goslings indicate significant changes in their body and may indicate activation of the cellular immune system.

Key words: amidostomosis, geese, hematological parameters, erythrocytes, eosinophils, leukocytes.

\section{Морфологічні показники крові гусей за амідостомозної інвазії}

\author{
С. М. Михайлютенко ${ }^{1}$, О. С. Жулінська ${ }^{2}$
}

${ }^{1}$ Полтавська державна аграрна академія, м. Полтава, Україна

${ }^{2}$ Інститут тваринництва степових районів імені М. Ф. Іванова “Асканія-Нова” - Національний науковий селекційно-генетичний центр з вівчарства, с. м. т. Асканія-Нова, Украӥна

\footnotetext{
Життєдіяльність організму водоплавної птиці залежить від багатьох чинників, але в периу чергу від стану системи еритроцитопоезу. Це унікальний механізм, який займає домінуючу позицію в забезпеченні тканинного дихання й стабільності обмінних процесів в організмі. На основі проведених досліджень і аналізу публікацій можна стверджувати, щзо зміни зі сторони еритроцитопоезу свідчать про патологічний стан, який на периих стадіях розвитку гельмінтозів перебігає без виражених клінічних ознак. Відомо, шзо нематода - Amidostoтит апsеris - гематофаг. Стан еритрочитопоезу найбільш вивчений у великої рогатої худоби та м'ясоїдних тварин. На теренах Украӥни недостатньо уваги приділено вивченню морфологічних показників у гусей. Тому з метою
} 
визначення впливу амідостом на морфологічні показники хворих гусенят сформовано дослідну групу птиці віком 1,5 місяиі, а також контрольну (вісім голів у кожній). Роботу виконували в умовах одноосібних селянських господарств с. Декабристи Миргородського району Полтавської області. Морфологічні показники вивчали за загальноприйнятими методами. У статті узагальнено результати експерименту щодо впливу амідостом на показники інвазованих гусенят породи велика сіра. 3 'ясовано, щзо паразитування у водоплавної птиці виду A. апsеris призводило до змін у загальному аналізі крові гусей: зниження вмісту гемоглобіну на 8,39, кількості еритрочитів - 13,46\%, достовірного значного підвищення кількості лейкочитів до 24,44 Г/л. Водночас здійснили морфологічне дослідження форменних елементів крові птиці з диференційним підрахунком лейкоцитарної формули. Встановлено зниження кількості сегментоядерних нейтрофілів $(22,0 \pm 0,57)$ порівняно з контрольною групою $(26,5 \pm 1,45)$ за рахунок лімфоцитів та моноцитів, щчо пов'язано, на нашу думку, з адаптацією організму до паразитування нематод. Результати морфологічних досліджень крові інвазованих гусенят вказують на істотні зміни в їх організмі й можуть свідчити про активізацію клітинної ланки iмунітету.

Ключові слова: амідостомоз, гуси, гематологічні показники, еритроцити, еозинофіли, лейкочити.

\section{Встуі}

Переважна більшість досліджень в паразитології стосуються, насамперед, поширення, видового складу нематодозів гусей, та морфологічних особливостей будови гельмінтів (Syrota et al., 2015; Yevstafieva et al., 2020; Melnychuk et al., 2020; Elshahawy et al., 2021). Небагаточисленні публікації анонсують вплив паразитів на організм птиці (Shutler et al., 2012; Conner et al., 2018; Sharma et al., 2019). Відомо, що гельмінти діють патогенно на органи й тканини господаря. Так, Єресько В. І. провів ряд досліджень, в ході яких встановив, що Capillaria anseris більш патогенна, ніж C. obsignata. Останнє підтверджується гематограмою хворих гусей 8-9 місяців. Так, у гусей, інвазованих C. anseris, діагностували зниження кількості еритроцитів на $32,4 \%$ та вмісту гемоглобіну на $11,5 \%$ (Yeresko, 2017).

Окрім того паразити порушують процес травлення та транзит кишкового вмісту (Padilla-Aguilar et al., 2020). Паразитування статевозрілих нематод спричиняє ушкодження, десквамацію епітелію ворсинок, некробіотичні процеси в поверхневих шарах слизової оболонки кишки та гіперплазію лімфатичної тканини (Panikar et al., 2016; Oyarzún-Ruiz et al., 2019).

Оскільки за гельмінтозів зникає апетит, це призводить до зменшення споживання корму, внаслідок чого знижується приріст маси (Al-Daraji \& Al-Amery, 2013). Так, встановлено, що маса домашніх курей, уражених Capillaria spp. менше на 37 г проти контрольної групи й на 111 г менше, ніж у птиці, інвазованої капіляріями й аскаридами (Bajramov, 2011). У результаті аналогічного дослідження відзначено, що загальний приріст за аскаридіозної інвазії становить 214 г, за аскаридіозно-гетеракозної - 201 г, у контрольній групі сягає аж 397 г (Bajramov, 2015). Всі перераховані вище фактори в поєднанні з підвищеними метаболічними потребами птиці спричиняють зниження опірності організму. Стан еритроцитопоезу найбільш вивчений у великої рогатої худоби та м'ясоїдних тварин (Anforova, 2017; Mynych et al., 2017). На теренах України недостатньо уваги приділено вивченню морфологічних показників у гусей.

Важливо підкреслити складність виконання та інтерпретації гемограми у птиці, головним чином через відсутність встановлення референтних значень для всіх видів; з різними значеннями в залежності від популяції, генетичних факторів, середовища проживання, географічного положення, статі, віку, фізіоло- гічного стану, сезонності та інше. Хоча вид гусей Anser domesticus вважається домашньою твариною, важко отримати сучасні фізіологічні дані про цей вид. Особливо стосовно гематологічних показників публікації $є$ поодинокими i, загалом неповними, хоча це один із найкращих способів аналізу життя та здоров'я птиці (Zaplatinsky \& Fedorovich, 2017).

Отже, масштабно вивчено епізоотологічні дані амідостомозу зарубіжними й вітчизняними науковцями. Але детально не проаналізованим залишається питання реакції організму хворої птиці на нематод. Тому мета наших досліджень полягала у встановлені впливу Amidostomum anseris на гематологічні показники інвазованих гусей. У завдання досліджень входило провести морфологічне дослідження формених елементів крові з диференційним підрахунком лейкоцитарної формули.

\section{Матеріал і методи досліджень}

Дослідження проводили упродовж літнього періоду 2021 року на базі наукової лабораторії кафедри паразитології та ветеринарно-санітарної експертизи Полтавської державної аграрної академії. Експериментальні досліди виконували в умовах одноосібних селянських господарств с. Декабристи Миргородського району Полтавської області. 3 метою визначення впливу амідостом на гематологічні показники хворих гусенят породи велика сіра сформовано дослідну групу птиці віком 1,5 місяці (спонтанно інвазовані самці), а також контрольну (клінічно здорові гуси) по вісім голів у кожній. Морфологічні показники вивчали за загальноприйнятими методами. Кількість еритроцитів і лейкоцитів підраховували у лічильній камері Горяєва (Zabolockij \& Poljakov, 1965). Лейкограму виводили з диференційним підрахунком лейкоцитів у мазках крові, пофарбованих за методом Папенгейма. Вміст гемоглобіну визначали гемоглобінціанідним методом (Kondrahin et al., 1985). Статистичну обробку результатів експериментальних досліджень проводили шляхом визначення середнього арифметичного $(\mathrm{M})$, його похибки (m) та рівня вірогідності (p) з використанням таблиці t-критеріїв Стьюдента.

\section{Результати та їх обговорення}

Під час проведення копроовоскопічних досліджень гусенят виявлено, що ступінь інтенсивності інвазії по групі коливався в межах 16-28 екземплярів 
яєць амідостом в одній краплі флотаційної рідини. Аналіз отриманих результатів дослідження гематоло- гічних показників хворих й здорових гусенят наведено в таблиці 1.

\section{Таблиця 1}

Гематологічні показники гусей, інвазованих нематодами виду Amidostomum anseris $(\mathrm{M} \pm \mathrm{m}, \mathrm{n}=8)$

\begin{tabular}{|c|c|c|c|}
\hline \multirow{2}{*}{\multicolumn{2}{|c|}{ Показники }} & \multicolumn{2}{|c|}{ Група птиці (самці) } \\
\hline & & контрольна & дослідна \\
\hline Гемоглобін, г/л & & $102,75 \pm 2,85$ & $94,13 \pm 2,08^{*}$ \\
\hline Еритроцити, Т/л & & $3,79 \pm 0,13$ & $3,28 \pm 0,11^{*}$ \\
\hline Лейкоцити, Г/л & & $19,03 \pm 1,44$ & $24,44 \pm 1,52 *$ \\
\hline \multicolumn{4}{|c|}{ Лейкограма, \% } \\
\hline Базофіли, \% & & - & - \\
\hline Еозинофіли, \% & & $10,62 \pm 1,01$ & $12,86 \pm 0,85$ \\
\hline \multirow{2}{*}{ Псевдоеозинофіли } & паличкоядерні & $1,13 \pm 0,29$ & $1,5 \pm 0,19$ \\
\hline & сегментоядерні & $26,5 \pm 1,45$ & $22,0 \pm 0,57^{*}$ \\
\hline Лімфоцити, \% & & $55,75 \pm 1,09$ & $58,63 \pm 1,15$ \\
\hline Моноцити,\% & & $6,0 \pm 0,34$ & $5,0 \pm 0,19^{*}$ \\
\hline
\end{tabular}

У ході вивчення патогенної дії нематод на організм гусей встановлено, що паразитування Amidostomum anseris характеризувалося змінами в крові хворих гусенят 3 боку кількості еритроцитів, лейкоцитів та вмісту гемоглобіну.

Так, з наведених даних видно, що зменшились показники: гемоглобіну на 8,39\%, а еритроцитів на $13,46 \%$ (Р < 0,05). Разом 3 тим відбулося вірогідне збільшення порівняно до контролю рівня лейкоцитів на $28,43 \%$ ( $<0,05)$, що вказує на прояв захисної реакції організму.

Морфологічне дослідження формених елементів крові гусей $з$ диференційним підрахунком лейкоцитарної формули вказує на перерозподіл показників, що можна пов'язати 3 адаптацією організму до паразитування амідостом. Відмічено зниження кількості сегментоядерних нейтрофілів $(22,0 \pm 0,57)$ порівняно 3 контрольною групою $(26,5 \pm 1,45)$. Водночас дані представлені в таблиці, свідчать про тенденцію до підвищення кількості еозинофілів та лімфоцитів.

Amidostomum anseris - видоспецифічна нематода водоплавної птиці (Enigk \& Dey-Hazra 1968; Wascher et al., 2012). Так, огляд фахової літератури свідчить про розшифрований цикл розвитку. Відомо, що водоплавна птиця зазвичай уражається, за рахунок поїдання безхребетних (проміжних господарів), але джерелом інвазування за амідостомозу гусей $є$ яйця та личинки (Enigk \& Dey-Hazra 1968; Yevstafieva et al., 2019). Будучи типовими гематофагами, амідостоми призводять до зменшення кількості еритроцитів і вмісту гемоглобіну в крові. Ці дані підтверджуються публікаціями датованими ще минулим століттям (Enigk \& Dey-Hazra 1968). У доступній сучасній літературі знайдено поодинокі зарубіжні публікації щодо вПливу амідостом на організ качок (Anah, 2012). За даними Григор'євої В. В. гематограма хворих амідостомозом гусей вказує на зниження вмісту гемоглобіну, кількості еритроцитів та збільшення кількості лейкоцитів. Вище перераховані висновки узгоджуються 3 проведеним нами експериментом (Grigoreva, 1996).
Еозинофілію у птиці реєструють рідко (Jahantigh, 2016). Вона пов'язана $з$ антигістамінною, антитоксичною та фагоцитарною функціями. Роль еозинофілів ще не досконало вивчено (Mitchell \& Johns, 2008; Benarrós et al., 2020). Нові дослідження доводять, що еозинофілія у птиці корелює 3 хронічним паразитизмом (Schmidt et al., 2007). Так, за даними ряду авторів кількість еозинофілів становила 10,7 проти 5,1 - у контрольної групи попугаїв уражених кнемідокоптесами (Shahabpour et al., 2019).

\section{Висновки}

Наявність Amidostomum anseris в організмі птиці істотно вплинула на показники еритроцитарної системи крові гусей. Так, рівень гемоглобіну у дослідних гусей був вірогідно нижчим (94,13 проти 102,75 г/л), що означає меншу насиченість еритроцитів гемоглобіном. Водночас звертає на себе увагу тенденція до збільшення відносної кількості лімфоцитів і зменшення псевдоеозинофілів.

Перспективи подальших досліджень. У подальшому планується детальне вивчення біохімічних показників сироватки крові хворих гусенят за амідостомозу.

Відомості про конфлікт інтересів. Автори стверджують про відсутність конфлікту інтересів щодо їх вкладу та результатів наукових досліджень.

\section{References}

Al-Daraji, Th. Kh., \& Al-Amery, A. M. (2013). Effect of different infective doses of Ascaridia galli eggs on the total serum protein and weight gain in white lohman laying hens. Al-Anbar Journal of Veterinary Sciences, 6(2), 105-112. URL: http://ejs-agri.com/uploads/pdf/ NewFolder/motmr2/1.pdf.

Anah, S. A., \& Anah, S. A. (2012). Study Comparison for haematological and biochemical changes in Ducks infeated with Amidostomum anseris. AL-Qadisiya Journal For Science, 17, 2. URL: 
http://qu.edu.iq/repository/wp-content/uploads/2017/ 04/2-5-2.د...pdf.

Anforova, M. V. (2017). Pokaznyky erytrotsytopoezu u sobak riznykh klimatychnykh zon Ukrainy. Naukovyi Visnyk Veterynarnoi Medytsyny, 1, 40-47 (in Ukrainian).

Bajramov, S. Yu. (2011). Vliyanie gelmintoznyh zabolevanij na produktivnost ptic. Izvestiya Nizhnevolzhskogo Agrouniversitetskogo Kompleksa: Nauka i Vysshee Professionalnoe Obrazovanie "Biologicheskie Nauki", 2(22), 1-5 (in Russian).

Bajramov, S. Yu. (2015). Prives cyplyat pri eksperimentalnom zarazhenii askaridiozom i geterakidozom. Vestnik Altajskogo Gosudarstvennogo Agrarnogo Universiteta, 12(134), 115-118 (in Russian).

Benarrós, M., Silva, C., Silva, G., \& Silva, K. (2020). Hematological Parameters of Geese Used in Biomedical Research. Brazilian Journal of Poultry Science, 22(2). doi: 10.1590/1806-9061-2019-1140.

Conner England, J., Levengood, J. M., Osborn, J. M., Yetter, A. P., Suski, C. D., Cole, R. A., \& Hagy, H. M. (2018). Associations of intestinal helminth infections with health parameters of spring-migrating female lesser scaup (Aythya affinis) in the upper Midwest, USA. Parasitology Research, 117(6), 18771890. doi: 10.1007/s00436-018-5879-6.

Elshahawy, I., El-Siefy, M., Fawy, S., \& Mohammed, E. (2021). Epidemiological Studies on Nematode Parasites of Domestic Geese (Anser anser f. domesticus) and First Molecular Identification and Phylogenetic Analysis of Heterakis dispar (Schrank, 1790) in Egypt. Acta Parasitologica, 2021. doi: 10.1007/s11686-021-00407-2.

Enigk, K., \& Dey-Hazra, A. (1968). Die perkutane Infektion bei Amidostomum anseris (Strongyloidea, Nematoda). Zeitschrift Fär Parasitenkunde, 31(2), 155-165. doi: 10.1007/bf00259541.

Enigk, K., \& Hazra, A. D. (1968). Zur Wirtsspezifität von Amidostomum anseris (Strongyloidea, Nematoda). Zeitschrift Fär Parasitenkunde, 31(3), 266-275. doi: $10.1007 / \mathrm{bf00259706.}$

Enigk, K., Schanzel, H., \& Hazra, A. D. (2010). Zur Pathogenität des Amidostomum befalles der Gans. Zentralblatt Für Veterinärmedizin Reihe B, 16(9), 784-798. doi:10.1111/j.1439-0450.1969.tb00161.x.

Grigoreva, V. V. (1996). Amidostomoz gusej v Chuvashskoj Respublike (epizootologiya, patogenez, klinika i lechenie): avtoreferat. Ivanovo (in Russian).

Jahantigh, M., \& Zamani-Ahmadmahmudi, M. (2016). Hematology and serum biochemistry values in greylag geese (Anser anser) in Southeast Iran. Comparative Clinical Pathology, 25(4), 671-675. doi: 10.1007/s00580-016-2273-6.

Kondrahin, I. P., Kurilov, N. V., \& Malahov, A. G. (1985). Klinicheskaja laboratornaja diagnostika V veterinarii:s pravochnoe izdanie. M.: Agropromizdat (in Russian).

Melnychuk, V. V., Yevstafieva, V. O., Borodai, Y. O., \& Lozhkina, O. V. (2020). Peculiarities of identifying capillariides parasatizing in poultry. Bulletin of
Poltava State Agrarian Academy, 2, 156-163. doi: 10.31210/visnyk2020.02.19.

Mitchell, E. B., \& Johns, J. (2008). Avian Hematology and Related Disorders. Veterinary Clinics of North America: Exotic Animal Practice, 11(3), 501-522. doi: 10.1016/j.cvex.2008.03.004.

Mynych, A. V., Antypov, A. A., \& Bakhur, T. Y. (2017). Vliyanie ezofagostomoznoj invazii na morfologicheskie i biohimicheskie pokazateli krovi krupnogo rogatogo skota. Naukovyi Visnyk Veterynarnoi Medytsyny, 1, 105-111 (in Russian).

Oyarzún-Ruiz, P., Muñoz, P., Paredes, E., Valenzuela, G., \& Ruiz, J. (2019). Gastrointestinal helminths and related histopathological lesions in black-necked swans Cygnus melancoryphus from the Carlos Anwandter Nature Sanctuary, Southern Chile. Revista Brasileira de Parasitologia Veterinária, 28(4), 613624. doi: 10.1590/s1984-29612019063.

Padilla-Aguilar, P., Romero-Callejas, E., RamírezLezama, J., Osorio-Sarabia, D., García-Prieto, L., Manterola, García-Márquez, C., L. J., \& Zarza, H. (2020). Gastrointestinal helminths of waterfowl (Anatidae: Anatinae) in the Lerma marshes of central Mexico: Some pathological aspects. International Journal for Parasitology: Parasites and Wildlife, 13, 72-79. doi: 10.1016/j.ijppaw.2020.07.008.

Panikar, I. I., Klymenko, A. S., Mykhailiutenko, S. M., \& Kruchynenko, O. V. (2016). Pathological changes in the chicken with mixed invasion of ascaridia galli and heterakis gallinarum. Bìoresursi ì Prirodokoristuvannâ, 8(3-4), 81-86. doi: 10.31548/bio2016.03.012.

Schmidt, E. M. S., Locatelli-Dittrich, R., Santin, E., \& Paulillo, A. C. (2007). Patologia clínica em aves de produção - uma ferramenta para monitorar a sanidade avícola - Revisão. Archives of Veterinary Science, 12(3), 9-12. doi: 10.5380/avs.v12i3.10906.

Shahabpour, A., Soroka, N. M., \& Pashkevych, I. Y. (2019). The influence of knemidocoptosis agents on general state of pet birds. Bulletin "Veterinary Biotechnology", 35, 144-152. doi: 10.31073/vet_biotech35-17.

Sharma, N., Hunt, P. W., Hine, B. C., \& Ruhnke, I. (2019). The impacts of Ascaridia galli on performance, health, and immune responses of laying hens: new insights into an old problem. Poultry Science, 98(12), 6517-6526. doi: 10.3382/ps/pez422.

Shutler, D., Alisauskas, R. T., \& Daniel McLaughlin, J. (2012). Associations between body composition and helminths of lesser snow geese during winter and spring migration. International Journal for Parasitology, 42(8), 755-760. doi: 10.1016/j.ijpara.2012.05.008.

Syrota, Y. Y., \& Kharchenko, V. O. (2015). Analysis of study comprehensiveness for nematode fauna of hydrophilic birds in Ukrainian Polissya. Annals of Parasitology, 61(3), 165-174. doi: 10.17420/ap6103.03.

Wascher, C. A. F., Bauer, A. C., Holtmann, A. R., \& Kotrschal, K. (2012). Environmental and social factors affecting the excretion of intestinal parasite eggs in graylag geese. Behavioral Ecology, 23(6), 1276-1283. doi: 10.1093/beheco/ars113.

Yeresko, V. I. (2017). Influence of capillaries on hematological parameters of infested geese. Bulletin 
of Poltava State Agrarian Academy, (1-2), 172-174. doi: 10.31210/visnyk2017.1-2.34.

Yevstafieva, V. A., Stybel, V. V., Melnychuk, V. V., Prijma, O. B., Yatsenko, I. V., Antipov, A. A., Bakhur, T. I., Goncharenko, V. P., Pidborska, R. V., Shahanenko, V. S., \& Dzhmil, V. I. (2019). Morphological and Biological Characteristics of Amidostomum Anseris (Nematoda, Amidostomatidae) from Anser anser domesticus. Vestnik Zoologii, 53(1), 65-74. doi: 10.2478/vzoo-2019-0007.

Yevstafieva, V., Starodub, Y., Melnychuk, V., \& Bakhur, T. (2020). Assessment of Time Periods of Exogenous Development of Trichostrongylus tenuis Nematodes, Parasitizing in Domestic Goose. Kocatepe Veterinary Journal, 1-1. doi: 10.30607/kvj.720849.
Yevstafieva, V., Yeresko, V., Melnychuk, V., \& Bakhur, T. (2020). Prevalence and Co-Infection of Baruscapillaria genus (Nematoda, Capillariidae) in Domestic Geese in Ukraine. Folia Veterinaria, 64(1), 32-38. doi: 10.2478/fv-2020-0005.

Zabolockij, V. T., \& Poljakov, V. F. (1965). Metodika podscheta eritrocitov krupnogo rogatogo skota na kolorimetre tipa FEK-N. Trudy vserossijskogo nauchno-issledovatelskij institut eksperimentalnoj veterinarii, 31, 281-286 (in Russian).

Zaplatinsky, V. S., \& Fedorovich, E. I. (2017). Morphological and biochemical blood indices of obroshinsky gray and obroshinsky white natural group geese ant its depending on their physiological state. Scientific Messenger LNUVMB, 19(79), 140-144. URL: https://core.ac.uk/download/pdf/235836924.pdf. 